\section{The torture doctors. Human rights crimes and the road to justice.}

Steven. H. Miles.

Georgetown University Press. 2020

\section{By Pau Pérez-Sales*}

Professor Steven Miles, in his recently published and long-awaited book, reviews the many ways in which a doctor may be complicit with torture.

Medical complicity has been an inherent part of the history of torture, in particular in the 20th century and with the beginning of contemporary forms of torture under French colonial rule in Algeria.

Professor Miles defines a torture doctor as: a licensed physician who directly and indirectly puts (a) medical knowledge or skills or (b) the authorities, duties or privileges conferred by the medical license in the service of "torture» or "cruel, inhuman or degrading treatment or punishment» as such terms are understood in international law.

He develops a catalogue of the ways that a health professional can be involved in torture practices. They can be summarised (chapters 1 to 4 and annex) into four categories:

1. Using their medical or psychological expertise to, directly or indirectly, inflict torture (e.g. medical or surgical procedures on the detainee, denial of analgesia, designing of physical or psychological torture methods, exploring or treating

^) Director, SiRa, Madrid.

Correspondence to: pauperez@runbox.com a patient in front of his or her torturers without privacy, allowing coercion and otherwise breaking privacy).

2. Performance of pseudo-medical or pseudo-psychological procedures considered as torture (e.g. forced anal examinations to determine alleged homosexuality, virginity tests, psychological tests to humiliate or discredit a victim, use of medical or psychiatric facilities to conceal the torture or as a form of torture in itself).

3. Writing medical records or carrying out examinations that ignore or distort essential information for the documentation of torture. For instance, the use of diagnoses that justify isolation of a person, using euphemisms that underestimate injuries or symptoms to show that they are banal or mild or superficial examinations or carrying out examinations that include irrelevant information. Also, documentation of facts that do not exist or have been manipulated; destruction of relevant clinical information; signing death certificates attributing the death to causes other than torture; destruction of evidence in autopsies; disclosure of information given during medical acts among others.

4. Conducting human medical or psychological research with prisoners without consent or without respecting the principles of research ethics.

Each one of these practices has occurred, and continues to occur, worldwide.

In Spain, the place from where this review is written, the works of Eva Forest (1987), who began collecting testimonies of torture in the Basque Country in the mid-1970s, documented the fundamental role of forensic doctors in cover-ups. In 1981, by way of an example case among many, Dr Esteban Muruetagoiena died after nine days of physical and 
psychological torture at the Guardia Civil facilities in San Sebastian and Madrid. The official autopsy certifies a natural death by a heart attack. The forensic certificate written following the death of Mikel Zabalza at the hands of the Civil Guard, tortured at the Intxaurrondo barracks in November 1985 reported: "death by immersion». It gave credence to the Civil Guard's version that during transportation, while handcuffed, Zabalza tried to escape and drowned while trying to cross the Bidasoa River. An independent inquiry by Danish forensic doctors supported the family's thesis that he had died due to torture by wet asphyxiation ("bathtub») and that the body was subsequently transported close to the river. On that occasion, the European Parliament issued a statement expressing its concern about the role of forensic doctors in Spain and demanding that they comply with the minimum standards required of forensic services in any, allegedly democratic, European country. The case was finally dismissed and archived in 2009. Since then, there has been little change regarding the role of official forensic doctors in Spain, as academic reports (some of them published in Torture Journal) show (Morentin et al., 2008; Petersen et al., 2002; Petersen \& Morentin, $2017,2019)$. There is extensive documentation, by way of another country example, on the role of doctors during the dictatorship in Chile. Doctors were directly involved, whether in uniform or not, in raids, accusations, denouncements or by direct execution of torture, as an Amnesty International (1983) fact-finding mission showed. Others took advantage of their political position to expel their colleagues from hospitals and to take over chairs and positions of service. The Chilean Truth and Reconciliation report (CNVR, 1991a, 1991b) also describes the issuing of forensic documents that were falsified by doctors. However, in a fascinating book, Rivas (1990) showed how the Chilean Medical Association was not able to prosecute those doctors, even under the restored democratic rule and instead preferred to look "the other way." Further, the Argentinian Never More report from the National Commission on the Disappearance of Persons (CONADEP, 1984) describes the conniving practice of doctors in the care of prisoners and detainees and the concealment of torture without legal consequences for those involved. Similar cases can be found in Uruguay (Bloche, 1986; SERPAJ, 1989) , Brazil (Arquidiocesis de Sao Paulo, 1985), Paraguay (Boccia et al., 2006), Peru (HRW, 1997) or Venezuela (Petersen, 1990), among others.

For several decades now, Mexico has been the country in Latin America where the role of forensic science has been most determinant in covering up the use of torture. The reports that denounce the fraudulent use of the Istanbul Protocol (IP) to cover up torture cases have been the subject of academic papers and reports. A recently published study analyzing 54 Istanbul Protocol reports carried out by official medical and psychological forensic experts by the Attorney General's Office (Fiscalía General de la República), shows how the IP has been used fraudulently to cover up torture practices (Grupo Independientes, 2020). The authors insist on the need for deontological and legal measures and demand that forensic services in Mexico are made independent ${ }^{1}$.

Unfortunately, in Latin America, the data shows that the determining factor for its occurrence was, in most cases, the doctors' identification with the cause of the institution, sharing their values and aims in regarding torture as a «lesser evil» to protect society from danger and criminality. This adds to coercion or fear

1 http://www.psicosocial.net/ 
of negative evaluation by the institution, and, in a minority of cases, an inadequate understanding of medical ethics. However, according to documentation and studies, empathy with perpetrators is the rule.

Those Latin American examples are similar to the many examples collected and detailed by Professor Steven Miles. He draws an «atlas» of torture doctors that shows that physicians are a «necessary» part of modern torture in at least one hundred countries, including in democracies. He details in chapter 6 carefully documented examples using sources in different languages and from different contexts. He makes a particular case for the United Kingdom (chapter 7) and the role of the British Medical Association in failing to take action when confronted with well-documented cases. This chapter parallels what happened with the American Psychiatric Association regarding Guantanamo and the Israeli Medical Association concerning the torture of Palestinian detainees, including minors (Yudkin, 2009). Chapter 10 brilliantly uncovers the disappointing role of the World Medical Association in compelling cases paralelling a similar situation that has recently occurred at the World Psychiatric Association, where a statement to forbid psychiatrists from participating in the interrogation of detainees took more than three years to obtain approval (PérezSales et al., 2018).

Professor Miles also reviews the fight for accountability with a particular focus on US policies and the ongoing efforts to combat medical complicity. For most doctors who do not work with torture survivors, torture is probably a minor problem that occurs in «small, far and distant» countries - something almost exotic. It is certainly not, for them, something to worry about in a democratic country. Furthermore, in torture practices, doctors would usually only be involved when there is no other option and surely are the "weakest element" in the chain of professionals that make torture and impunity possible. It would not be fair to make them accountable. But professor Miles shows that this is a naïve viewpoint. The author finally concludes that impunity is the rule, something that he finds "profoundly disturbing».

This book, a necessary read, confronts courts, medical boards and professional associations and asks for an end to this practice of looking the other way. We encourage the readers to navigate its pages and take action. When one doctor is part of a torturing system, all doctors are concerned.

\section{References}

Amnistia Internacional. (1983). La tortura en Chile (Torture in Chile). London.

Arquidiocesis de Sao Paulo. (1985). Torture in Brazil: a Shocking Report on the Pervasive Use of Torture by Brazilian Military Governments, 1964-1979, Secretly Prepared by the Archdiocese of São Paulo. Vozes. vasive-use-of-torture-bybrazilian-military-governments-1964-1979/ oclc/45727633\&referer=brief_results

Bloche, M. G. (1986). Uruguay's Military Physicians Cogs. FAMA, 255(20).

Boccia, A., Portillo, C., \& Arestivo, C. (2006). Medicos Etica y Tortura en el Paraguay (Doctors, Ethics and Torture in Paraguay). Arandura ediciones. Asunción..

CNVR. (1991a). Informe de la Comisión Nacional de Verdad y Reconciliación. Vol 1. (National Truth and Reconciliation Commission.). Santiago de Chile.

CNVR. (1991b). Informe de la Comisión Nacional de Verdad y Reconciliación. Vol 2.

CONADEP. (1984). Nunca Más. Informe de la Comisión Nacional sobre la Desaparición de Personas. EUDEBA. (Never More. Report of the National Commission of the Forced Dissappearance of Persons)

Forest, E. (1987). 10 años de tortura y democracia. (10 years of torture and democracy) Gestoras Pro Amnistia - Euskadi.

Grupo Independientes. (2020). Encubriendo la tortura. Complicidad de los forenses de la Procuraduría General de la República. Análisis de 54 casos. (Hidding torture. Complicity of forensic experts of the Attorney General Office. Analysis of 54 
cases) Irredentos Libros.

Morentin, B., Callado, L. F., \& Idoyaga, M. I. (2008). A follow-up study of allegations of ill-treatment / torture in incommunicado detainees in Spain. Methods, February, 87-98.

Pérez-Sales, P., Jan den Otter, J., Hardi, L., Wenzel, T., Diaconu, G., Cors, G., \& Kastrup, M.

(2018). WPA Position Statement on Banning the Participation of Psychiatrists in the Interrogation of Detainees. World Psychiatry, 17(2), 237-238. https://doi.org/10.1002/wps.20539

Petersen, H., \& Morentin, B. (2017). Detainees' perception of the doctors and the medical institution in Spanish police stations: An impediment in the fight against torture and ill-treatment. Torture fournal, 27(2). https://doi. org/10.7146/torture.v27i2.97217

Petersen, H., \& Morentin, B. (2019). Assessing the level of credibility of allegations of physical torture. Forensic Science International, 301, 263-270. https://doi.org/10.1016/j. forsciint.2019.05.043

Petersen, H., Morentin, B., \& Callado, L. F. (2002). Assessment of the Quality of Medical Documents Issued in Central Police Stations in Madrid, Spain : The Doctor's Role in the Prevention of. fournal of Forensic Sciences, 47(4), 293-299.

SERPAJ. (1989). Uruguay. Nunca Mas. Montevideo.

Yudkin, J. S. (2009). The Israeli Medical Association and doctors' complicity in torture. BMF, 339(oct07 1), b4078-b4078. https://doi. org/10.1136/bmj.b4078 